This is the author's version of a work that was accepted for publication in the Journal of Contemporary Accounting \& Economics. Changes resulting from the publishing process, such as peer review, editing, corrections, structural formatting and other quality control mechanisms may not be reflected in this document. Changes may have been made to this work since it was submitted for publication. A definitive version was subsequently published in the Journal of Contemporary Accounting \& Economics, Volume 10, Issue 1, April 2014, Pages 1-15. http://doi.org/10.1016/j.jcae.2013.11.003 


\title{
Incentives for Corporate Tax Planning and Reporting: Empirical Evidence from Australia
}

\author{
Grantley Taylor \\ School of Accounting, Curtin Business School \\ Curtin University \\ GPO Box U1987 \\ Perth, Western Australia, Australia 6845 \\ Tel: +61-8-9266-3377 \\ Fax: +61-8-9266-7196 \\ grantley.taylor@cbs.curtin.edu.au
}

\author{
Grant Richardson \\ School of Accounting and Finance, the Business School \\ University of Adelaide \\ 10 Pulteney Street \\ Adelaide, South Australia \\ AUSTRALIA 5005 \\ Tel: +61-8-83130582 \\ Fax: +61-8-82234782 \\ grant.richardson@adelaide.edu.au
}




\title{
Incentives for Corporate Tax Planning and Reporting: Empirical Evidence from Australia
}

\begin{abstract}
This study extends prior research on the willingness of firms to significantly decrease their corporate taxes. It specifically examines the associations between corporate tax avoidance and the reported significant uncertainty of a firm's tax position, the tax expertise and tax affiliations of its directors, and the performance-based remuneration incentives of its key management personnel. Based on a dataset of 200 publicly listed Australian firms over the 2006-2010 period (1,000 firm years), we find that the reported uncertainty of a firm's tax position, the tax expertise of its directors, and the performance-based remuneration incentives of its key management personnel are significantly positively associated with tax avoidance. Conversely, firms with board members who have at least one tax-related affiliation are significantly negatively associated with tax avoidance.
\end{abstract}

Keywords: corporate tax avoidance, tax uncertainty, directors' tax expertise, directors' tax affiliation, performance-based management remuneration incentives.

JEL Classifications: H25; H26; K34.

\section{Introduction}

Corporate taxes can adversely affect a firm's financial position, financial performance, liquidity, operational results and cash flows (Grubert and Mutti, 1991; Shackelford and Shevlin, 2001; Dhaliwal et al., 2005; Beattie et al., 2006). This study extends prior research on the willingness of firms to aggressively decrease their corporate taxes. It specifically investigates the associations between corporate tax avoidance ${ }^{1}$ and the reported significant uncertainty of a firm's tax position, the tax expertise and tax affiliation of its directors, and the performancebased remuneration incentives of its key management personnel. We examine the association between the reporting of uncertain tax positions and tax avoidance given that the Australian Taxation Office (ATO) requires firms to report uncertainties regarding tax positions, tax payable

\footnotetext{
${ }^{1}$ Corporate tax avoidance is defined in this study as any transaction or event ("passive” or "aggressive") that leads to a reduction in the amount of corporate taxes paid by a firm (see, e.g., Dyreng et al., 2008). Tax avoidance may be achieved through legitimate methods in accordance with tax legislation provisions. In fact, tax reduction methods may be either passive (complying with tax provisions) or aggressive (structuring transactions or activities with one of the principle objectives to decrease the amount of corporate taxes). Tax avoidance may alternatively be achieved through illegal means or means that are not in compliance with tax legislation provisions. These particular methods constitute tax evasion.
} 
and tax recovery. The management and disclosure of tax risks by firms has come under increasing scrutiny by the ATO. Prior research has either provided little in the way of relating specific corporate governance and remuneration attributes to corporate tax avoidance or provided mixed results. We thus examine the associations between tax avoidance and specific board attributes such as tax experience, tax affiliation, and the performance-based remuneration incentives of key management personnel to determine whether managerial opportunities, incentives and capabilities exacerbate or impede the likelihood of tax-aggressive planning.

Australian firms have come under increased monitoring by the ATO and other tax authorities such as the Internal Revenue Service (IRS) for a range of corporate tax avoidance activities. In particular, income shifting, strategic debt placement, research and development deductions, bad debt deductions, interest expense deductions, and the use of tax havens have recently been major areas of the ATO’s focus (2010; 2012). In fact, according to the ATO: “Australia’s top 200 listed companies are deriving significantly more of their income from overseas sources. Multinational groups may attempt to structure their global operations to minimize tax costs by, for example, maximizing the proportion of their profits recorded in low-tax jurisdictions” (ATO, 2012, p. 43). Recent media releases have also emphasized the ability of multinational firms operating in Australia (e.g., Apple, Google and Starbucks) to exploit the differences in tax laws, rules and regulations across multiple jurisdictions to significantly decrease the amount of corporate taxes they pay internationally (Australian Financial Review, 2012).

Using a dataset of 200 publicly listed Australian firms over 2006-2010 (1,000 firm years), we find that the reported uncertainty of a firm's tax position, the tax expertise of its directors, and the performance-based remuneration incentives of its key management personnel are significantly positively associated with corporate tax avoidance. On the other hand, firms with 
board members who have at least one tax-related affiliation are significantly negatively associated with tax avoidance.

This study makes several important contributions. First, it investigates the association between corporate tax avoidance and a firm's reported uncertainties of its tax position, which has not been explicitly examined in prior studies. Our findings suggest that the disclosure of uncertainty related to the calculation of a firm's tax position is significantly positively associated with tax avoidance. Indeed, firms are likely to disclose tax uncertainties due to their participation in complex and obfuscatory tax avoidance activities. Risky or aggressive tax planning may obscure the firm's actual performance and decrease the information content of its taxable income. Second, this study examines the associations between tax avoidance and other variables such as directors' tax expertise, directors' affiliations with tax-related bodies (e.g., with The Board of Taxation and/or The Institute of Taxation), and the performance-based remuneration incentives of key management personnel, and is one of the first to do so. Third, this study complements other recent studies on tax avoidance carried out in the U.S. (e.g., Armstrong, 2012; Cheng et al., 2012; McGuire et al., 2012) by analyzing the tax-motivated activities of publicly listed Australian firms on which there is negligible evidence in the literature.

The remainder of the paper is organized as follows. Section 2 considers the related theory and develops hypotheses. Section 3 reports the research design. Section 4 provides the empirical results. Finally, Section 5 concludes the paper.

\section{Background and hypotheses development}

Dyreng et al. (2008) observe that the behavior of key executives may have a significant effect on the level and nature of corporate tax avoidance as a result of how they influence the internal 
control and risk functions of firms and their management. In fact, Frank et al. (2009) find a positive association between tax and financial reporting aggressiveness. They provide examples of firms engaging in the earnings management of taxable profits and financial profits simultaneously, with their book income managed upward ("aggressive financial reporting”) and their taxable income managed downward (“aggressive tax reporting”) during the same reporting period. Firms that exhibit aggressive tax and financial earnings management strategies at the same time tend to have concomitant aggressive investing, financing, operating and compensation strategies (Frank et. al., 2009).

Revsine et al. (2002) claim that the tax footnotes in a firm's annual report may be used to provide a more informed assessment of its current and future performance. They also argue that an increase in deferred tax liability may be an early signal of deteriorating earnings quality. Moreover, studies by Lev and Nissan (2004), Hanlon (2005) and Hanlon et al. (2007) find that larger book-tax differences (BTDs) are significantly associated with earnings persistence and timeliness. Thus, the disclosure of uncertainties related to the derivation of tax estimates may decrease the informativeness of BTDs. For example, uncertainties in the derivation of tax estimates due to the existence of operations in variably taxed jurisdictions could result in adjustment uncertainty via differential tax rates in the book-tax reconciliation statements. ${ }^{2}$

In this paper, we argue that variables pertaining to the reported uncertainty of a firm's tax position, the tax expertise and tax affiliations of its board members, and the remuneration-based incentives of its key management personnel are significant determinants of corporate tax avoidance.

\footnotetext{
${ }^{2}$ Assistant Australian Treasurer David Bradbury further emphasizes that: "large multinational companies that use complex arrangements and contrived corporate structures to avoid paying their fair share of tax should not be able to hide behind a veil of secrecy" (The Treasury, 2012, p. 2). To that end, the ATO now requires large firms to report on their tax positions from 2012 if required, specifically as they relate to the likelihood of tax liabilities and any tax uncertainties the firm may have in terms of its reportable transactions (ATO, 2012).
} 


\subsection{Reported uncertainty of a firm's tax position}

Recent research has considered the reporting of uncertain tax positions supported by complex international arrangements as indicative of aggressive tax behavior (e.g., Mills et al., 2010; Rego and Wilson, 2012; Lisowsky et al., 2013). ${ }^{3}$ Aggressive tax strategies impose significant uncertainty for a firm in terms of applying tax legislation and deriving tax estimates. Uncertainties over current tax liability (or current tax asset) estimates may be reported in a firm's financial statement notes if its management faces significant uncertainty in estimating the firm's tax liabilities (e.g., provision for taxes based on the global variability in taxes to be paid) or assets (e.g., estimates of deferred tax assets based on the criteria that tax losses will probably be recouped at a future point). When a firm reports significant tax uncertainty, it signals that it is facing certain tax risks. These risks occur due to the high likelihood of a mismatch between the reported tax expense (and liability) of the firm's tax returns (and financial statements) and what the firm should be paying the tax authority (e.g., the ATO). They are exacerbated when the firm is engaged in complex arrangements with management, and when auditors encounter difficulties in correctly applying tax legislation.

The increased focus on tax risks in Australia and the U.S. has been prompted by the complex arrangements of multinational firms, including the widespread use of operations domiciled in OECD (2006) listed tax havens (see Appendix A). The recent implementation of reportable tax positions by the ATO (or FIN 48 Accounting for Uncertainty in Income Taxes in the U.S.) ${ }^{4}$

\footnotetext{
${ }^{3}$ Consistent with Hanlon and Heitzman's (2010) study, tax positions or determinations are viewed conceptually as falling along a continuum from highly certain ("least aggressive") to highly uncertain ("most aggressive").

${ }^{4}$ FIN 48 Accounting for Uncertainty in Income Taxes, effective for the fiscal years beginning after December 15, 2006, is classified as Accounting Standards Codification (ASC) 740-10-25 under the Financial Accounting Standards Board's (FASB's) new codification for U.S. generally accepted accounting principles (GAAP).
} 
requires firms to analyze and disclose their income tax risks ${ }^{5}$ and uncertainty in terms of their tax positions and tax payable or tax recovery. ${ }^{6}$

Given the demand for greater disclosure of tax risks and uncertainties by the ATO and IRS, boards of directors (and audit committees) are now examining how firms manage their tax risks. In particular, the ATO and IRS stress that the board must take charge in evaluating the firm's tax profile, the strategies of its tax department, the process by which tax uncertainties are identified and documented, and the procedures in place to integrate tax analysis into business decisions. Further, the board must ensure that the firm's overall risk management programs address tax risks. The board, which liaises with a tax manager and audit committee, is required to understand the firm's uncertain tax position, significant judgments and estimates and internal controls, in addition to the tax issues surrounding its major transactions (KPMG, 2010).

Alexander et al. (2008) measure corporate tax avoidance in the U.S. by examining the amount of unrealized tax benefits that would influence effective tax rates (ETRs) if realized, and the interest and penalties associated with unrealized tax benefits based on FIN 48. In Australia, an entity must disclose any tax-related contingent liabilities and contingent assets in accordance with AASB 137 Provisions, Contingent Liabilities and Contingent Assets (AASB, 2010). Contingent liabilities and assets may arise, for example, from unresolved tax disputes with the ATO. Australian firms recognize liabilities for anticipated tax audit issues based on management's estimate of whether additional corporate taxes are payable sometime in the future.

\footnotetext{
${ }^{5}$ According to the results of a 2011-2012 tax risk survey conducted by Ernst and Young (2012), 75\% of firm executives experienced a rise in the volume of aggressiveness of tax audits, and $97 \%$ of the tax authorities surveyed indicated that tax risk related to international structures and cross-border transactions would be on the tax enforcement radar over the next three years.

${ }^{6}$ For instance, the ATO requires large firms to file a statement entitled Uncertain Tax Positions along with their 2011 and later tax returns, signifying the pervasive nature of these uncertainties and the related concern of the tax authorities.
} 
This occurs if the firm's final tax outcome is different from the current and deferred tax estimates in the current accounting period.

Wilson (2010) claims that firms with the propensity to use off-balance-sheet financing tend to have no or significantly lower reported interest expenses in their annual reports compared with the quantum of interest expenses reflected in their tax returns, which generates tax deductions. Wilson's (2010) assertions are based on research by Mills and Newberry (2005), who find that firms with lower credit ratings report lower interest expenses in their annual reports compared with that recorded in tax returns. It is thus possible that tax avoidance is associated with the reporting of significant uncertainties over the derivation of tax estimates in the annual report.

The complex nature of transactions makes it difficult for stakeholders to fully evaluate firm performance, including the tax implications of these transactions or arrangements (Desai and Dharmapala, 2007). Balakrishnan et al. (2011) find that firms that exhibit aggressive tax planning tend to display increased financial and organizational complexity and decreased information transparency. Lisowsky et al. (2013) observe a positive association between firms that disclose a tax reserve in their financial statements and their use of tax shelters as a principle mechanism to reduce the amount of taxes they pay. These studies show that tax disclosures (or more specifically, the disclosure of significant uncertainties in the derivation of tax estimates and ultimately taxable income) may be useful ex-ante in identifying firms that are aggressively decreasing their corporate tax liabilities. Firms that record uncertainty in their tax estimate derivations reduce the informativeness of accounting income to taxable income reconciliation statements in their financial statements, and may thus affect the decisions of their investors.

Prior studies have suggested that financial statement disclosures of tax information provide estimates of a firm's tax liability that are opaque at best (Lisowsky, 2007). Uncertainty over tax 
accounting estimates is a potential determinant of corporate tax avoidance. Managers may exploit their inherent subjectivity when estimating tax amounts to facilitate tax avoidance, as judgments are required on the application and interpretation of income tax legislation, on calculating the quantum of deferred taxes, on the creation of tax reserves related to ongoing or potential tax audits, and on the ability of the firm to recoup carry-forward tax losses (CFTLs). The complexities and obscurity related to tax planning in multiple jurisdictions are likely to give rise to uncertainties when deriving tax estimates. To formally test the association between corporate tax avoidance and a firm's reported uncertainties of its tax position, the following hypothesis is proposed.

H1: The disclosure of a significant uncertainty over a firm's tax position is positively associated with corporate tax avoidance, ceteris paribus.

\subsection{Tax expertise of directors}

The board of directors represents the apex of decision control within a firm. It is ultimately responsible for monitoring the firm's management and its major strategic and operational decisions (Fama and Jensen, 1983). Dyreng et al. (2010) claim that directors and top management personnel influence risky or aggressive tax planning by establishing a tone and framework of compliance for a firm. Recent research (e.g., Frank et al., 2009; Dyreng et al., 2010) has suggested that aggressive tax planning is associated with managerial opportunism and capabilities. Hanlon and Slemrod (2009) argue that the directors of some large multinational firms state in their annual reports that they owe it to shareholders to decrease taxes through any permissible, legitimate and legal means. Board members who have tax expertise are thus able to effectively use their professional ability to monitor and provide information to managers, and to 
monitor the firm's compliance with applicable tax laws (Carter et al., 2010). However, the development and implementation of arrangements to significantly decrease a firm's corporate tax liability requires the coordination of a diverse group of professionals, including the tax department, legal advisors, accountants, auditors and financial advisors, all of whom may offer tax advice as an input to these arrangements.

If board members have the requisite tax experience, they may contribute the necessary resources toward the development of tax arrangements and add significantly to the effective tax function in terms of decreasing the firm's corporate tax liabilities (Maydew and Shackelford, 2005). Directors who have prior tax experience may identify additional opportunities due to their expertise in approving and formulating tax plans. Their incentive would be to increase the aftertax returns to shareholders, which may also include themselves (Maydew and Shackelford, 2005). To formally test the influence of board members' tax expertise on corporate tax avoidance, the following (non-directional) hypothesis is proposed.

H2: Board members who have tax expertise are associated with corporate tax avoidance, ceteris paribus.

\subsection{Tax affiliations of directors}

Firms and their directors may suffer reputational damage from ongoing or future tax audits, especially when aggressive tax schemes or arrangements become public knowledge. Recent cases in Australia (e.g., James Hardie) and the U.S. (e.g., Apple, Google and Starbucks) have shown that public scrutiny and commentary in the public media may affect investor sentiment and ultimately firm value (Hanlon and Slemrod, 2009). ${ }^{7}$ Hanlon and Slemrod (2009) cite

\footnotetext{
${ }^{7}$ News about tax aggressive activities may affect share prices and firm valuations either positively or negatively (Hanlon and Slemrod, 2009). For instance, Hanlon and Slemrod (2009) find that the share prices of U.S. firms
} 
examples of large U.S. multinational firms (e.g., General Electric) that disclose statements in their annual reports to indicate that their tax strategies should not be harmful to their reputations. The firms infer from these disclosures that their management is concerned about being labeled as “tax aggressive” or "poor corporate citizens” if they were to, for example, establish tax strategies that relied excessively on the use of tax havens. In fact, such a concern arises due to the flow-on reputational and political costs that ensue because of negative media attention.

If the members of a firm's board of directors are affiliated with various professional taxrelated bodies that are connected to the government, then they are more likely to ensure that the firm's tax practices conform with legal requirements (i.e., the tax acts applicable to the jurisdictions in which the firm operates), professional body requirements, peer practices and community expectations and values. Non-conformity with these requirements and practices may negatively affect the reputations of the board members and the firm. Thus, the directors and firms exposed to the potential reputational damage resulting from non-conformity are more likely to adhere to legal and professional requirements and demands and less likely to engage in tax aggressive activities. In fact, according to the Australian Inspector-General of Taxation: “At the same time, these companies also need to assess the maintenance of social and political relationships for each given jurisdiction in which business is conducted. Large business companies are typically subject to significant levels of public and regulatory forms of scrutiny and are not in a position to pay out corporate funds without a legal or commercial obligation. Directors also have a range of important legal obligations imposed upon them personally in addition to the companies they represent” (Inspector-General of Taxation, 2011, p. 3). ${ }^{8}$ To

decline on average when their involvement in tax havens is publicly disclosed. The negative backlash appears to be focused on firms in the retail sector and less so on firms that have high cash ETRs.

${ }^{8}$ The directors of Australian firms are directly responsible for ensuring that corporate taxes are paid, and that the firms comply with tax legislation pursuant to the Taxation Administration Act 1953 (Cth). 
formally test the influence of board member tax affiliation on corporate tax avoidance, we propose the following hypothesis.

H3: Firms with board members who have tax affiliations are negatively associated with corporate tax avoidance, ceteris paribus.

\subsection{Performance-based remuneration incentives of key management personnel}

The motivation of key management personnel (i.e., directors and executives) to engage in corporate tax avoidance could be influenced by remuneration incentives (Watts and Zimmerman, 1990; Walsh and Ryan, 1997). Nevertheless, Phillips (2003) finds no evidence that CEOs whose bonuses are tied to after-tax earnings performance are more motivated to engage in tax avoidance. Desai and Dharmapala (2006) examine the association between management compensation and tax avoidance. They propose that increased compensation helps to align the incentives of agents and principals in an agency framework that induces management to undertake risky investment, finance and tax decisions. This association can be inverted if the managerial rent diversion and the use of tax havens act as substitutes for each other. Desai and Dharmapala (2006) find that an increase in incentive compensation decreases the use of tax havens by firms that have weak corporate governance structures.

Dyreng et al. (2010) assert that directors set the "tone at the top" in terms of a firm's compensation arrangements, which may have flow-on consequences that are related to tax compliance. Minnick and Noga (2010) find that remuneration for directors and CEOs is associated with lower long-run ETRs. Rego and Wilson (2012) argue that equity-based remuneration incentives motivate managers to undertake risky tax planning. Managers with proportionately larger at-risk-cash- and equity-based (share-based payment and options) 
remuneration are motivated to increase after-tax returns for shareholders and the firm, and one of the most effective ways to achieve this is to decrease the amount of the firm's income tax expense. Performance-based remuneration incentives provide managers with sufficient compensation to undertake risky and aggressive tax activities that typically lead to tax avoidance. These risks could include the uncertainty related to a firm's tax position, a loss of reputation capital and the costs associated with audits initiated by tax authorities. Rego and Wilson's (2012) results provide some support for these assertions. They associate managers of firms that have proportionately greater equity-based remuneration with lower (accounting and cash) ETRs and wider BTDs (Rego and Wilson, 2012).

Armstrong et al. (2012) investigate the association between tax director compensation and the measures of U.S. firm tax aggressiveness. They find a strong negative association between tax director compensation incentives and accounting ETRs, but no significant association with cash ETRs. This result suggests that the accounting tax expense may be a more informative measure of executive actions on taxes. In addition, Armstrong et al. (2012) find no significant association between compensation incentives and BTDs. ${ }^{9}$

In examining the association between remuneration-based incentives and tax avoidance, any potential linkage may not necessarily be the direct result of tax planning but instead be the result of a concerted effort by the board of directors and executives to decrease corporate tax liabilities. For instance, any association may be the result of a firm's normal commercial activities, which along with investing and financing activities may also include activities designed to decrease the amount of corporate taxes paid (Armstrong et al., 2012).

\footnotetext{
${ }^{9}$ Gaertner (2013) similarly document a significant negative association between after-tax CEO incentives and accounting ETRs.
} 
Based on the aforementioned discussion, we expect a positive association between the performance-based remuneration of key management personnel and corporate tax avoidance. This assertion is formalized in the following hypothesis.

H4: Performance-based remuneration incentives of key management personnel are positively associated with corporate tax avoidance, ceteris paribus.

\section{Research design}

\subsection{Sample selection and data source}

Our sample for empirical testing initially consisted of the top 300 publicly listed Australian firms over 2006-2010. ${ }^{10}$ However, we excluded financial firms (39), insurance firms (11), U.S. GAAP reporting firms (16), property partnership or trust entities (11), and firms that did not report across all five years of the 2006-2010 period because they were newly incorporated, were taken over or merged with other firms (23). The final sample thus consists of 200 firms (1,000 firm years). Finally, all of the tax and financial-accounting-related data were hand-collected from the annual reports.

\subsection{Dependent variable}

To improve the robustness of our results, we employ four measures of corporate tax avoidance (i.e., ETRs and BTDs) that have been implemented in prior studies as our dependent variable (see, e.g., Manzon and Plesko, 2002; Desai and Dharmapala, 2006; Dyreng et al., 2008, 2010; Chen et al., 2010; Cheng et al., 2012; McGuire et al., 2012). Each measure of tax

\footnotetext{
${ }^{10}$ The sample period of 2006-2010 was chosen due to the significant level of activity carried out by the ATO in terms of its reviews and audits of large-firm tax planning over the period (ATO, 2010).
} 
avoidance is a reflection of tax planning that decreases a firm's tax liability without necessarily decreasing its accounting income.

Our first tax avoidance measure (ETR1) is calculated as the total tax expense (comprising both current and deferred tax expenses) scaled by pre-tax accounting income. The second (ETR2) is calculated as cash taxes paid scaled by pre-tax accounting income. A disadvantage of using accounting tax expense is that it comprises current and deferred tax expenses, and the latter may result from large deferred tax adjustments (Hanlon, 2005). The advantage of using cash taxes being paid over accounting tax expense is that tax avoidance strategies are more likely to be reflected in cash outlays for tax rather than accounting tax expense (Dyreng et al., 2008). Cash tax outlays can be reduced using strategies that involve increasing deductions and decreasing taxable income. However, when computing ETRs based on cash taxes paid, significant cash payments related to settlements with the ATO on prior-year tax returns can present a problem. Finally, negative measures of ETR1 and ETR2 concern the presence of income tax refunds or benefits. If a sample firm received an income tax refund in a given year, we set its ETR measures at zero in line with the study by Dyreng et al. (2008).

We also used BTDs as a measure of corporate tax avoidance (Graham et al., 2012). Firms that are relatively successful at avoiding taxes are likely, although not necessarily always able, to sustain large differences between their accounting and taxable income (Alexander et. al., 2008; Dyreng et al., 2008; Frank et al., 2009; Rego and Wilson, 2012). In fact, transactions can be structured to generate large temporary or permanent differences in the two kinds of income. ${ }^{11}$ Our third tax avoidance measure (BTAX1) assesses the raw BTD as per a study by Manzon and Plesko (2002), calculating it as the pre-tax accounting income less the taxable income and scaled by lagged total assets. Taxable income is computed as income tax expense divided by the

\footnotetext{
${ }^{11}$ For instance, the use of R\&D tax credits can lead to permanent BTDs.
} 
corporate statutory tax rate of $30 \%$. The fourth tax avoidance measure (BTAX2) is calculated as the BTD residual using the method developed by Desai and Dharmapala (2006). ${ }^{12}$ They argue that rather than reflecting increased levels of tax avoidance, the BTD may reflect earnings management activities in which income is adjusted to avoid reporting losses or to achieve performance benchmarks or remuneration-based objectives. Following Desai and Dharmapala (2006), we adjust the BTD to control for the earnings management activities that could be responsible for the difference. In particular, we remove the BTD component attributable to earnings management to leave a residual value that is inferred to measure corporate tax avoidance (Desai and Dharmapala, 2006).

\subsection{Independent variables}

Our independent variables are denoted by the reporting of a significant uncertainty related to a firm's tax position (TRU), director tax expertise (TAXEXP), director tax affiliation (TAXAFF), and the performance-based remuneration incentives of the firm's key management personnel (REM).

TRU is measured as a dummy variable of 1 if the firm discloses a significant uncertainty related to its tax position and 0 otherwise. We collect this information from the financial statement notes in firms' annual reports. TAXEXP is measured as a dummy variable of 1 if at least one member of the firm's board of directors has tax expertise (i.e., prior experience in tax accounting or tax-related audit work) and 0 otherwise. TAXAFF is measured as a dummy variable of 1 if at least one member of the firm's board of directors has a minimum of one

\footnotetext{
${ }^{12}$ A description of the method developed by Desai and Dharmapala (2006) for calculating the BTD residual is provided in Appendix B.
} 
affiliation to a tax-related professional body (i.e., The Board of Taxation ${ }^{13}$ and/or The Institute of Taxation) and 0 otherwise. We obtain the information related to directors' tax expertise or affiliation from the directors' report or the corporate governance section of firms' annual reports. REM is measured as the total performance-based remuneration incentives paid to the firm's key management personnel (i.e., the total at-risk cash bonus and total equity-based remuneration paid to the key management personnel) scaled by the total remuneration paid to the key management personnel. We collect the information related to the remuneration of key management personnel from the remuneration reports.

\subsection{Control variables}

Our study includes several control variables pertaining to firm size, leverage, capital intensity, R\&D intensity, inventory intensity, CFTLs, tax haven use, the market-to-book value of equity, operating performance (i.e., return on assets), board of director independence, Big 4 auditor designation, CEO tenure, industry sectors effects and year effects.

Firm size (SIZE) controls for the effect of the size of the firm on tax avoidance. Rego (2003) observes that larger firms can achieve economies of scale via tax planning and have resources and incentives to decrease group tax. SIZE is measured as the natural log of total assets.

Leverage (LEV) is included as a control variable because it is expected that firms that have higher debt-to-equity ratios are more efficient at minimizing corporate taxes. Rego (2003) finds that higher-leveraged firms have lower ETRs, as they use debt deductions to significantly decrease the amount of corporate taxes they pay. LEV is measured as long-term debt scaled by total assets.

\footnotetext{
${ }^{13}$ The Board of Taxation is an independent, non-statutory body established to advise the Australian government on the development and implementation of tax legislation, and the ongoing operation of the tax system.
} 
Capital intensity (CINT) and inventory intensity (INVINT) are included as control variables for highly capital-intensive or inventory-intensive firms, respectively (Stickney and McGee, 1982). CINT is positively associated with tax avoidance due to the accelerated depreciation charges based on asset lives. So far as INVINT is a substitute for CINT, inventory-intensive firms should be less tax avoidant than capital-intensive firms; thus, INVINT is negatively associated with tax avoidance (Stickney and McGee, 1982). We measure CINT as net property, plant and equipment scaled by total assets, and INVINT as inventory scaled by total assets.

We also incorporate R\&D intensity (RDINT) as a control variable in our study, as prior research has found it to be positively associated with tax avoidance owing to the tax-deductible nature of R\&D expenditure (Gupta and Newberry, 1997; Richardson and Lanis, 2007). We measure RDINT as R\&D expenditure scaled by total assets.

CFTLs are also included as a control variable. Dyreng et al. (2008) find that firms with CFTLs have the opportunity to use them in the future to offset revenue or capital gains and significantly decrease the amount of corporate taxes they pay. The use of CFTLs in a given accounting period may thus reflect a firm's tax-planning activities, which may in turn indicate its wider tax avoidance behavior (Dyreng et al., 2008). CFTL is measured as a dummy variable of 1 when a firm has CFTLs and 0 otherwise.

Tax haven use (THAV) (measured as a dummy variable of 1 if the firm has at least one subsidiary firm incorporated in an OECD (2006) listed tax haven and 0 otherwise) controls for the firm's use of tax havens. Studies by Desai et al. (2006), Desai and Hines (2002), Dharmapala and Hines (2009), and Taylor and Richardson (2012) find tax haven use to be positively associated with corporate tax avoidance. 
We also include a growth control variable represented by MKTBK (measured as the market value of equity scaled by the book value of equity) (Gupta and Newberry, 1997) in our study. However, due to the conflicting results obtained for MKTBK in prior research, we make no sign prediction for this variable.

We incorporate return on assets (ROA) (measured as the pre-tax income scaled by the total assets) into our study to control for the firm's operating performance (Gupta and Newberry, 1997). No sign prediction is made for ROA due to the conflicting results in prior research.

Board of director independence (BODI) controls for differences in the monitoring capacity of directors on the firm’s board. Fama and Jensen (1983) assert that independent directors have a greater incentive to monitor firm management, and possess knowledge and skills that may assist them in making firm-related decisions. Concern for reputation in the labor market also provides independent directors with a greater incentive to act in the best interest of shareholders when monitoring management vis-à-vis non-executive directors (Coles et al., 2008). BODI is measured as the proportion of board members who are independent directors.

Big 4 audit firm use (AUD) is included in our study to control for firm monitoring and audit quality (Matsumura and Tucker, 1992; Rezaee, 2005). AUD is measured as a dummy variable of 1 if the firm employs a Big 4 external auditor and 0 otherwise. However, due to the conflicting results obtained for AUD in prior research, we make no sign prediction for this variable.

CEO tenure (CEO) is also included as a control variable, and reflects the degree of managerial power and experience of the firm's CEO. In fact, CEOs with greater power are likely to receive more compensation (Bugeja at al., 2013) and have greater control over firm management, which may have flow-on effects for tax risk management and reporting. CEO is measured as the natural log of the CEO’s tenure (in years). No sign prediction is made for this variable. 
The following industry-sector (INDSEC) dummy variables defined at the two-digit GICS code level are included as control variables, as it is possible for tax avoidance to fluctuate across different industry sectors (Omer et al., 1993): capital goods, consumer service retail, energy, food, stables and beverage, materials, media, pharmaceuticals and health care, real estate, transport, and utilities (the omitted sector in our regression model). No sign predictions are made for these variables.

Finally, we include year dummy variables (YEAR) in our regression model to control for the differences in corporate tax avoidance or other activities that potentially existed over the 20062010 sample years (with 2010 being the omitted year in our regression model). No sign predictions are made for these variables.

\subsection{Regression model}

Our ordinary least squares (OLS) regression model, which we use to examine the incentives for corporate tax planning and reporting, is estimated as follows:

$$
\begin{aligned}
& \mathrm{CTA}_{\mathrm{it}}=\alpha_{\mathrm{it}}+\beta_{1} \mathrm{TRU}_{\mathrm{it}}+\beta_{2} \mathrm{TAXEXP}_{\mathrm{it}}+\beta_{3} \mathrm{TAXAFF}_{\mathrm{it}}+\beta_{4} \mathrm{REM}_{\mathrm{it}}+\beta_{5} \mathrm{SIZE}_{\mathrm{it}}+\beta_{6} \mathrm{LEV}_{\mathrm{it}} \\
& +\beta_{7} \mathrm{CINT}_{\text {it }}+\beta_{8} \mathrm{RDINT}_{\mathrm{it}}+\beta_{9} \mathrm{INVINT}_{\text {it }}+\beta_{10} \mathrm{CFTL}_{\mathrm{it}}+\beta_{11} \mathrm{THAV}_{\mathrm{it}}+\beta_{12} \mathrm{MKTBK}_{\text {it }} \\
& +\beta_{13} \mathrm{ROA}_{\mathrm{it}}+\beta_{14} \mathrm{BODI}_{\mathrm{it}}+\beta_{15} \mathrm{AUD}_{\mathrm{it}}+\beta_{16} \mathrm{CEO}_{\mathrm{it}}+\beta_{17-25} \mathrm{INDSEC}_{\mathrm{it}}+\beta_{26-29} \mathrm{YEAR}_{\mathrm{it}} \\
& +\varepsilon_{\mathrm{it}}
\end{aligned}
$$

where $\mathrm{i}=$ firms $1-200 ; \mathrm{t}=$ the financial years 2006-2010; CTA $=$ the corporate tax avoidance proxy measures (ETR1, ETR2, BTAX1 and BTAX2); TRU = a dummy variable of 1 if the firm discloses a significant uncertainty of its tax position and 0 otherwise; TAXEXP $=$ a dummy variable of 1 if at least one member of the board of directors has tax expertise (i.e., prior experience in tax accounting or tax-related audit work) and 0 otherwise; TAXAFF $=$ a dummy 
variable of 1 if at least one member of the board of directors has a minimum of one affiliation to a tax-related professional body (i.e., The Board of Taxation and/or The Institute of Taxation) and 0 otherwise; REM = the total performance-based remuneration incentives paid to key management personnel (the total at-risk cash bonus and total equity-based remuneration paid to the key management personnel) scaled by the total remuneration paid to the key management personnel; SIZE = the natural logarithm of total assets; LEV = long-term debt scaled by total assets; CINT $=$ net property, plant and equipment scaled by total assets; RDINT $=$ R\&D expenditure scaled by total assets; INVINT $=$ total inventory scaled by total assets; CFTL $=\mathrm{a}$ dummy variable of 1 when a firm has CFTLs and 0 otherwise; THAV = a dummy variable of 1 if the firm has at least one subsidiary firm incorporated in an OECD (2006) listed tax haven and 0 otherwise; MKTBK = the market value of equity scaled by the book value of equity; ROA = pretax income scaled by total assets; BODI = the proportion of board members who are independent directors; $\mathrm{AUD}=$ a dummy variable of 1 if the firm employs a Big 4 external auditor and 0 otherwise; $\mathrm{CEO}=$ the natural logarithm of the CEO's tenure (in years); INDSEC = a dummy variable of 1 if the firm is represented in the specific GICS category and 0 otherwise; YEAR = a dummy variable of 1 if the year falls within the specific year category and 0 otherwise; and $\varepsilon=$ the error term.

\section{Empirical results}

\subsection{Descriptive statistics}

Table 1 reports the descriptive statistics for the dependent variables (ETR1, ETR2, BTAX1 and BTAX2), independent variables (TRU, TAXEXP, TAXAFF and REM) and control variables (SIZE, LEV, CINT, RDINT, INVINT, CFTL, THAV, MKTBK, ROA, BODI, AUD and CEO). 
The dependent variables ETR1, ETR2, BTAX1 and BTAX2 have means of 0.160, 0.195, 0.029 and -0.003 , respectively. The independent variable TRU has a mean of 0.373 , indicating that around $37.3 \%$ of the sample firms disclose a significant uncertainty related to the derivation of their tax estimates. ${ }^{14}$ TAXEXP and TAXAFF have means of 0.083 and 0.086 respectively, indicating that $8.3 \%$ of the firms have board members who have tax expertise and that $8.6 \%$ of the firms have directors who are affiliated with a tax-related professional body. REM has a mean of 0.345 , indicating that the total (at-risk) performance-based remuneration incentives component for the key management personnel is $34.5 \%$ of the total remuneration. The mean, median and range of the control variables are also presented in Table 1.

We collect additional (untabulated) data related to tax-experienced and tax-affiliated directors from the director reports or corporate governance section of the annual reports to ascertain whether these directors could influence their boards' tax planning and tax risk management activities. In terms of the tax-experienced directors, $70.83 \%$ are independent non-executive directors and $29.17 \%$ are non-independent directors, $8.33 \%$ of whom constitute managing directors. Tax-experienced directors are well represented on committees, including $25 \%$ on audit committees, $16.66 \%$ on risk committees, $4.1 \%$ on compliance committees, $29.16 \%$ on nomination committees, and $20.83 \%$ on remuneration committees. For the tax-affiliated directors, 95\% are independent non-executive directors, $10 \%$ of whom constitute board chairs, and 5\% are non-independent directors. Tax-affiliated directors are also well represented on board committees, including $55 \%$ on audit committees, $35 \%$ on risk committees, $10 \%$ on compliance committees, $30 \%$ on nomination committees and $20.83 \%$ on remuneration committees. Of the 23

\footnotetext{
14 The sample firms disclose significant uncertainty in the derivation of their tax estimates in relation to: (a) the quantum and timing of deferred taxes (26); (b) global tax provisions (32); (c) the use of CFTLs (32); (d) tax deductions (4); (e) ongoing tax audits (2) and (f) the application of income tax legislation (10). The sample firms also typically disclose significant uncertainties in the derivation of their tax estimates for more than one area.
} 
firms with tax-experienced directors and 20 firms with tax-affiliated directors, five firms have both tax-experienced and tax-affiliated directors on their boards. ${ }^{15}$ These data suggest that the tax-experienced and tax-affiliated directors are likely able to influence board decisions given their significant representation on board committees and that many of these directors are members of two or three committees. The tax-affiliated directors are far more independent as a whole and are better represented on the audit, risk and compliance committees compared with the tax-experienced directors. Further, the tax-affiliated directors may have a greater monitoring capacity in terms of ensuring that their firms' tax risks are adequately managed and that their tax compliance is at a high level. ${ }^{16}$

\section{[Insert Table 1 About Here]}

\subsection{Correlation results}

The Pearson pairwise correlation results are presented in Table 2. Significant correlations are found between ETR1, ETR2 and BTAX2 and the independent variables TRU, TAXEXP, TAXAFF and REM, and the control variables SIZE, LEV, RDINT, INVINT, CFTL, THAV, ROA, BODI, AUD and CEO ( $p<0.10$ or better). However, no significant correlations are found between BTAX1 and the independent variables. Table 2 also indicates that only moderate levels of collinearity exist between the independent variables used in this study ${ }^{17}$ In particular, the highest correlation coefficient of 0.425 is found between LEV and SIZE $(p<0.01)$. Finally, we calculate variance inflation factors (VIFs) when estimating the regression model to test for signs of multi-collinearity between the independent variables. Our (untabulated) results confirm that

\footnotetext{
${ }^{15}$ Of these five firms, two have separate tax-experienced and tax-affiliated board members. Cases where the same board member has both tax experience and tax affiliations are not likely to influence the results.

${ }^{16}$ Research by John and Senbet (1998) finds that a board's effectiveness may be affected by not only its composition (e.g., size, CEO power, independence, experience and affiliations) but also its administrative structure. Boards may use committees to facilitate long-run tax planning decisions that are designed either to enhance after-tax wealth maximization for the firm and its shareholders or to monitor top-level management.

${ }^{17}$ Hair et al. (2006) indicate that a correlation coefficient value for a pair of explanatory variables between \pm 0.25 and \pm 0.75 exhibits a moderate level of collinearity between the two variables.
} 
none of the VIFs exceed five for any of our independent variables. As such, multi-collinearity does not present a problem for our study (Hair et al., 2006). ${ }^{18}$

\section{[Insert Table 2 About Here]}

\subsection{Regression results}

Table 3 reports the results of the OLS regression model. The regression coefficient for TRU is negative and significantly associated with ETR2 $(p<0.10)$ and is positive and significantly associated with both BTAX1 $(p<0.10)$ and BTAX2 $(p<0.01)$. Thus, H1 is supported by the results. Firms that report a significant uncertainty in the derivation of tax estimates have lower cash ETRs, suggesting that firms engaging in complex and potentially obfuscatory tax avoidance activities generally pay lower taxes. In addition, firms that report significant uncertainty related to the calculation of their tax estimates have wider BTDs. The regression coefficient for TAXEXP is negative and significantly associated with ETR1 $(p<0.05)$ and is positive and significantly associated with both BTAX1 $(p<0.10)$ and BTAX2 $(p<0.01)$, so H2 is supported. Firms with directors who possess tax-related expertise tend to have lower accounting ETRs and wider BTDs. The regression coefficient for TAXAFF is positive and significantly associated with both ETR1 $(p<0.05)$ and ETR2 $(p<0.01)$ and is negative and significantly associated with BTAX2 $(p<0.01)$. Accordingly, H3 is supported by the results. Firms with board members who possess tax-related affiliations are expected to have higher ETRs. This potentially reflects a firm's adherence to tax laws, owing to its reputational concerns and lower likelihood of aggressive tax planning. Moreover, firms with directors who are affiliated with tax-related bodies are likely to have smaller BTDs. The regression coefficient for REM is negative and significantly associated with ETR1 $(p<0.10)$ and ETR2 $(p<0.05)$ and is positive and

\footnotetext{
${ }^{18}$ Hair et al. (2006) advise that a VIF value above the threshold of ten corresponds with a high level of multicollinearity among the explanatory variables.
} 
significantly associated with BTAX2 $(p<0.05)$. Therefore, H4 is supported. Firms with key management personnel who derive a proportionately greater amount of performance-based remuneration incentives from at-risk-cash- and share-based payments have lower ETRs and wider BTDs. The directors and senior executives of these firms may have the incentive to significantly avoid corporate taxes, because at-risk-cash- and equity-based remuneration is closely tied to after-tax earnings. Finally, in terms of the control variables, tax avoidance is shown to be significantly associated with SIZE, LEV, INVINT, CFTL, MKTBK, ROA, AUD and CEO in several of our regression model specifications ( $p<0.10$ or better). ${ }^{19}$

\section{[Insert Table 3 About Here]}

\subsection{Propensity matching scores}

A potential limitation of our prior analysis is that the independent variables TAXEXP, TAXAFF and REM may suffer from a self-selection bias. In other words, a board may select directors with particular tax experience or affiliations or remunerate members based on the tax complexities faced by the firm, which may not be systematically associated with our tax avoidance measures. To the extent that the linearity assumption of our OLS regression analysis is violated, the prior analysis may be mis-specified, resulting in biased coefficient estimates.

As a robustness check of our main regression results reported in Table 3, we implement a propensity matching analysis in two steps (see, e.g., Rosenbaum and Rubin, 1983; Armstrong et al., 2012; Lennox et al., 2013). First, we run separate logit regression models for TAXEXP and TAXAFF, and an OLS regression analysis for REM for each year. The explanatory variables used in each model include TRU along with the control variables (SIZE, LEV, CINT, RDINT, INVINT, CFTL, THAV, MKTBK, ROA, BODI, AUD, CEO and INDSEC). TAXEXP,

\footnotetext{
${ }^{19}$ As a basic robustness check of our regression results, we run separate cross-sectional OLS regressions for each of the years during the 2006-2010 period. The (untabulated) results are similar in scope to those reported in Table 3.
} 
TAXAFF and REM are also included as independent variables contingent upon the specific dependent variable used. The predicted estimates from each model are used as the propensity scores for each firm-year observation. Second, we form "one-to-one" matched pairs for TAXEXP, TAXAFF and REM, respectively, based on the propensity scores. In a majority of the cases, the propensity scores are matched to two decimal places in the analysis.

Consistent with the econometric procedure used by Lennox et al. (2013), we include all of the economic and corporate governance variables in our regression models. Although little theoretical work has modeled the determinants of board member TAXEXP and TAXAFF, prior research has provided some evidence of the variables that are likely to influence the appointment of such directors to a board. For example, larger firms are more likely to require the services of directors with some tax knowledge and tax affiliations due to complex multinational financial and tax planning arrangements, and the need to keep abreast of new corporate tax administration and tax legislation application developments. Firms with complex operating, financial and monitoring structures are likely to benefit from the appointment of independent directors who have a range of expertise and affiliations (Linck et al., 2008). In addition, Linck et al. (2008) claim that because oversight costs increase in line with firm complexity and operation intensity, boards require members who have diverse sets of skills and networks. As evidenced by R\&D tax concessions (aligned with R\&D intensity), directors who have tax experience and/or tax affiliations may self-select to firms that are larger, have more complex tax arrangements, have CFTLs, and have tax-haven-incorporated subsidiaries.

In terms of REM, directors may self-select to larger, more profitable and more complex firms (in terms of capital structure, capital intensity, R\&D intensity and tax planning arrangements) that are likely to pay larger at-risk-cash- and/or equity-based remuneration compared with 
smaller, less-complex firms (Hutchinson and Gul, 2006). Larger firms also tend to be characterized by more independent boards, use Big 4 external auditors and have longer-serving CEOs (Linck et al., 2008). The size and complexity of a firm are also considered important in determining the level of performance-based remuneration. Larger, more complex firms attract more experienced and qualified board members, and pay for such quality and expertise (Hutchinson and Gul, 2006). REM may also be associated with the strength of a firm's corporate governance structure and CEO influence (Matolcsy et al., 2012; Bugeja et al., 2013).

We establish three sets of matched pairs of firm years. Although their observable characteristics are similar, their TAXEXP, TAXAFF and REM variables are dissimilar. We are able to effectively match 168, 172 and 512 firm-year observations for TAXEXP, TAXAFF and $\mathrm{REM}^{20}{ }^{20}$ respectively. After matching on these variables, any difference in the outcome of interest (i.e., ETR1, ETR2, BTAX1 and BTAX2) can be attributed to the differences in TAXEXP, TAXAFF and/or REM rather than to the differences in the other variables. We perform separate (untabulated) t-tests of the differences in ETR1, ETR2, BTAX1 and BTAX2 on each of the matched samples of TAXEXP, TAXAFF and REM, respectively. ${ }^{21} \mathrm{We}$ find significant differences in ETR1, ETR2, BTAX1 and BTAX2 overall in terms of the matched samples of TAXEXP, TAXAFF and REM ( $p<0.10$ or better).

We report the regression results based on the matched samples in Table 4. Consistent with the results provided in Table 3, statistically significant regression coefficients are shown for TRU, TAXEXP, TAXAFF and REM and several of the tax avoidance measures (ETR1, ETR2, BTAX1 and BTAX2) for the subsamples based on matched director tax expertise and matched

\footnotetext{
${ }^{20}$ The performance-based remunerations are divided into two groups (i.e., "high" and "low"), separated by the median value of REM.

${ }^{21}$ Because the differences in means of ETR1, ETR2, BTAX1 and BTAX2 are normally distributed, we use t-tests in our analysis.
} 
director tax affiliation ( $p<0.10$ or better). However, REM shows slightly less-significant regression coefficients for the subsample based on the total performance-based remuneration incentives paid to key management personnel ( $p<0.10$ or better). Overall, the matching analysis tends to show that our regression results are attributable to systematic differences in the presence of directors who have tax expertise, and affiliations and the total performance-based remuneration incentives paid to key management personnel rather than to differences in the other characteristics.

\section{[Insert Table 4 About Here]}

\section{Conclusion}

This study examines the association between corporate tax avoidance and a firm's reported uncertainty of its tax position, the tax expertise and affiliations of its directors, and the performance-based remuneration incentives of its key management personnel. Our results show that a firm's reported uncertainty of its tax position, the tax expertise of its directors, and the performance-based remuneration incentives of its key management personnel are significantly positively associated to tax avoidance. Further, firms with board members who have at least one tax-related affiliation display a significantly negative association with tax avoidance.

Our findings are important given that corporate tax avoidance represents an outcome of managerial opportunism, incentives and capabilities. This appears to be the first study to explicitly examine the association between tax avoidance and a firm's reported uncertainty of its tax position. In fact, the reporting of uncertain tax positions could assist tax authorities in gauging the nature of aggressive tax arrangements from publicly available information (e.g., the annual report), and has important implications for financial reporting. Our study also appears to be one of the first to empirically examine the associations between tax avoidance, the tax 
expertise and affiliations of a firm's directors, and the performance-based remuneration incentives of a firm's key management personnel. The significant associations found between these variables in our empirical analysis highlight the key roles that directors and top management personnel play in influencing a firm's aggressive or risky tax planning activities. An important upshot of our findings is that various tax authorities (e.g., the ATO and the IRS) have recently demanded greater disclosure of firms' tax risks. Hence, corporate boards are now taking a harder look at how firms are managing tax risks.

This study is subject to several limitations. First, our sample is drawn from publicly listed Australian firms, and we develop proxy measures of tax avoidance due to the private and confidential nature of corporate tax data. Second, this study focuses only on Australia. To determine the generalizability of our findings, it may be useful to conduct similar analyses in other jurisdictional settings such as Canada, the U.K. and the U.S.

\section{References}

AASB, 2010. AASB 137 Provisions, Contingent Liabilities and Contingent Assets. AASB, Melbourne. November 2010. Available at: http://www.aasb.gov.au.

Alexander, R., Ettredge, M., Stone, M., and Sun, L. 2008. Assessing corporate tax aggressiveness. Working Paper, University of Kansas.

Armstrong, C.S., Blouin, J.L., and Larcker, D.F. 2012. The incentives for tax planning. Journal of Accounting and Economics 53, 391-411.

Australian Financial Review, 2012. Tax charge based on hypocrisy, 23 November 2012. Available at: http://www.afr.com/p/tax_charge_based_on_hypocrisy_3boTCV0W6CYvt82sH0A8PO.

Australian Taxation Office, 2010. Large Business and Tax Compliance. ATO, Canberra, ACT. Available at: http://www.ato.gov.au.

Australian Taxation Office, 2012. Compliance Program 2012-13. ATO, Canberra, ACT. Available at: http://www.ato.gov.au.

Balakrishnan, K., Blouin, J., and Guay, W. 2011. Does tax aggressiveness reduce financial reporting transparency? Working Paper, Wharton School, University of Pennsylvania.

Beattie, V., Goodacre, A., and Thomson, S.J. 2006. Corporate financing decisions: UK survey evidence. Journal of Business, Finance and Accounting, 33(9/10), 1402-1434.

Bugeja, M., Matolcsy, Z., and Spiropoulos, H. 2013. Gender-diverse compensation committees and their association with CEO compensation and excess CEO compensation. Working Paper, University of Technology, Sydney. 
Carter, D.A., Simkins, B.J., and Simpson, W.G. 2003. Corporate governance, board diversity and firm value. Financial Review 38, 33-53.

Chen, S., Chen, X., Cheng, Q., and Shevlin, T. 2010. Are family firms more tax aggressive than non-family firms? Journal of Financial Economics 95, 41-61.

Cheng, C.S.A., Huang, H.H., Li, Y., and Stanfield, J. 2012. The effect of hedge fund activism on corporate tax avoidance. The Accounting Review 87(5), 1493-1526.

Coles, J.L., Guay, W.R., and Larker, D.F. 2008. The power of the pen and executive compensation. Journal of Financial Economics 88; 1-25.

Desai, M.A., and Dharmapala, D. 2006. Corporate tax avoidance and high-powered incentives. Journal of Financial Economics, 79, 145-179.

Desai, M.A., and Dharmapala, D. 2007. Taxation and corporate governance: an economic approach. Taxation and Corporate Governance Conference, Munich.

Desai, M.A., and Hines, J.R. 2002. Expectations and expatriations: tracing the causes and consequences of corporate inversions. National Tax Journal, 55(3), 409-440.

Desai, M.A., Foley, C.F., and Hines, J.R. 2006. The demand for tax haven operations. Journal of Public Economics, 90, 513-531.

Dhaliwal, D.S., Newberry, K.J., and Weaver, C.D. 2005. Corporate taxes and financing methods for taxable acquisitions. Contemporary Accounting Research, 22(1), 1-30.

Dyreng, S., Hanlon, M., and Maydew, E. 2008. Long-run corporate tax avoidance. The Accounting Review, 83(1), 61-82.

Dyreng, S.D., Hanlon, M., and Maydew, E. 2010. The effects of managers on corporate tax avoidance. The Accounting Review, 85(4), 1163-1189.

Ernst and Young, 2012. Considering Global Tax Risk and Uncertainty. Board Matters Quarterly, April 2012. Available at: http://www.ey.com/GL/en/Services/Tax/2011-12-Tax-risk-andcontroversy-survey.

Fama, E.F., and Jensen, M., 1983. Agency problems and residual claims. Journal of Law and Economics, 26(2), 327-349.

Frank, M.M., Lynch, J.L., and Rego, S.O. 2009. Are financial and tax reporting aggressiveness reflective of broader corporate policies? The Accounting Review, 84(2), 467-496.

Gaertner, F.B. 2013. CEO after-tax compensation incentives and corporate tax avoidance. Working Paper, Nanyang Business School, Nanyang Technological University, Singapore.

Graham, J.R., Raedy, J.S., and Shackelford, D.A. 2012. Research in accounting for income taxes. Journal of Accounting and Economics, 53, 412-434.

Grubert, H., and Mutti, J. 1991. Taxes, tariffs and transfer pricing in multinational corporate decision making. Review of Economics and Statistics, 73, 285-293.

Gupta, S., and Newberry, K. 1997. Determinants of the variability in corporate effective tax rates: evidence from longitudinal data. Journal of Accounting and Public Policy, 16, 1-34.

Hair, J.F., Black, W.C., Babin, B.J., Anderson, R.E., and Tatham, R.L. 2006. Multivariate Data Analysis. Sixth Edition, Upper Saddle River, NJ, Pearson Prentice-Hall.

Hanlon, M. 2005. The persistence and pricing of earnings, accruals, and cash flows when firms have book-tax differences. The Accounting Review, 80(1), 137-166.

Hanlon, M., and Heitzman, S. 2010. A review of tax research. Journal of Accounting and Economics, 50, 127-178.

Hanlon, M., Mills, L., and Slemrod, J. 2007. An empirical examination of corporate tax noncompliance. In A. Auerbach, H. Hines, and J. Slemrod (Eds.), Taxing Corporate Income in the $21^{\text {st }}$ Century, pp. 171-210. Cambridge University Press, Cambridge. 
Hanlon, M., and Slemrod, J. 2009. What does tax aggressiveness signal? Evidence from stock price reactions to news about tax shelter involvement. Journal of Public Economics, 93(1/2), $126-141$.

Healy, P. 1985. The effect of bonus schemes on accounting decisions. Journal of Accounting and Economics, 7, 85-107.

Hutchinson, M., and Gul, F.A. 2006. The effects of executive share options and investment opportunities on firms' accounting performance: some Australian evidence. The British Accounting Review, 38(3), 277-297.

Inspector-General of Taxation, 2011. Report into the Australian Taxation Office's Large Business Risk Review and Audit Policies, Procedures and Practices. Australian Government, Canberra, ACT.

John, K., and Senbet, L.W. 1998. Corporate governance and board effectiveness. Journal of Banking and Finance, 22, 371-403.

KPMG, 2010. Public Policy Alert 8 - The Increasing Importance of Tax Risk Oversight: Recent Perspectives from Tax Administrators. Available at: http://www.kpmg.com/sg/en/issuesandinsights/cfopublications/pages/publicpolicyalert8taxri skoversight_cfoinsights.aspx.

Lennox, C., Lisowsky, P., and Pittman, J. 2013. Tax aggressiveness and accounting fraud. Journal of Accounting Research, 51 (4), 739-778.

Lev, B., and Nissan, D. 2004. Taxable income, future earnings and equity values. The Accounting Review, 79(4), 1039-1074.

Linck, J.S., Netter, J.M., and Yang, T. 2008. The determinants of board structure. Journal of Financial Economics, 87(2), 308-328.

Lisowsky, P. 2007. Inferring U.S. tax liability from financial statement information. Working Paper, Boston University.

Lisowsky, P., Robinson, L., and Schmidt, A. 2013. Do publicly disclosed tax reserves tell us about privately disclosed tax shelter activity? Journal of Accounting Research 51 (3), 583629.

Manzon G., and Plesko, G. 2002. The relation between financial and tax reporting measures of income. Tax Law Review, 55, 175-214.

Matsumura, E.M., and Tucker, R.R. 1992. Fraud detection: a theoretical foundation. The Accounting Review, 67(4), 753-782.

McGuire, S.T., Omer, T.C., and Wang, D. 2012. Tax avoidance: does tax-specific industry expertise make a difference? The Accounting Review, 87(3), 975-1003.

Matolcsy, Z., Shan, Y., and Seethamraju, V. 2012. The timing of changes in CEO compensation from cash bonus to equity-based compensation: determinants and performance consequences. Journal of Contemporary Accounting and Economics, 8(2), 78-91.

Maydew, E.L., and Shackelford, D.A. 2005. The changing role of auditors in corporate tax planning. NBER Working Paper No. 11504.

Mills, L.F., and Newberry, K.J. 2005. Firms' off-balance sheet and hybrid debt financing: evidence from their book-tax reporting differences. Journal of Accounting Research, 43(2), 251-281.

Mills, L., Robinson, L., and Sansing, R. 2010. FIN 48 and tax compliance. The Accounting Review, 85(5), 1721-1742.

Minnick, K., and Noga, T. 2010. Do corporate governance characteristics influence tax management? Journal of Corporate Finance, 16, 703-718. 
Phillips, J. 2003. Corporate tax planning effectiveness: the role of compensation-based incentives. The Accounting Review, 78(3), 847-874.

Rego, S.O. 2003. Tax-avoidance activities of U.S. multinational corporations. Contemporary Accounting Research, 20(4), 805-833.

Rego, S., and Wilson, R. 2012. Equity risk and corporate tax aggressiveness. Journal of Accounting Research, 50(3), 775-810.

Revsine, L., Collins, D.W., and Johnson, W.B. 2004. Financial Reporting and Analysis. Upper Saddle River, NJ, Pearson/Prentice Hall.

Richardson, G., and Lanis, R. 2007. Determinants of the variability in corporate effective tax rates and tax reform: evidence from Australia. Journal of Accounting and Public Policy, 26(6), 689-704.

Rosenbaum, P., and Rubin, D. 1983. The central role of the propensity score in observational studies for causal effects. Biometrika, 70, 41-55.

Shackelford, D.A., and Shevlin, T. 2001. Empirical tax research in accounting. Journal of Accounting and Economics, 31(2), 321-387.

Stickney, C., and McGee, V. 1982. Effective corporate tax rates: the effect of size, capital intensity, leverage, and other factors. Journal of Accounting and Public Policy, 1(2), 12552.

Taylor, G., and G. Richardson. 2012 International corporate tax avoidance practices: evidence from Australian firms. International Journal of Accounting, 47: 469-496.

The OECD, 2006. The OECDs Project on Harmful Tax Practices: 2006 update on progress in member countries. Available at: http://www.oecd.org/dataoecd/1/17/37446434.pdf.

The Treasury. 2012. Greater transparency of tax paid by large and multinational businesses. Press Release No. 5. Australian Government, Canberra. Available at: http://assistant.treasurer.gov.au/DisplayDocs.aspx?doc=pressreleases/2013/005.htm\&pageI $\mathrm{D}=003 \& \min =$ djba\&Year=\&DocType.

Walsh, E.J., and Ryan, J. 1997. Agency and tax explanations of security issuance decisions, Journal of Business Finance and Accounting, 24(7/8), 943-961.

Watts, R.L., and Zimmerman, J.L. 1990. Positive accounting theory: a ten year perspective. The Accounting Review, 65(1), 131-156.

White, H.A., 1980. Heteroskedasticity-consistent covariance matrix estimator and a direct test for heteroskedasticity. Econometrica, 48, 817-838.

Wilson, R. 2010. Discussion of "credit ratings and taxes: The effect of book-tax differences on ratings changes.” Contemporary Accounting Research, 27(2), 403-411. 


\section{Appendix A \\ OECD (2006) Listed Tax Havens}

The OECD's (2006) 33 tax havens are represented as follows: Anguilla, Antigua and Barbuda, Bahamas, Bahrain, Bermuda, Belize, British Virgin Islands, Cayman Islands, Cook Islands, Cyprus, Dominica, Gibraltar, Grenada, Guernsey, Isle of Man, Jersey, Liberia, Malta, Marshall Islands, Mauritius, Montserrat, Nauru, Netherlands Antilles, New Caledonia, Panama, Samoa, San Marino, Seychelles, St. Lucia, St. Kitts and Nevis, St. Vincent and the Grenadines, Turks and Caicos Islands and Vanuatu. 


\section{Appendix B \\ Description of Desai and Dharmapala's (2006) Method for Computing the Book-tax Gap Residual}

Applying the Desai and Dharmapala (2006) methodology, taxable income is calculated as $\mathrm{TI}_{\mathrm{it}}=$ accounting income tax expense divided by the corporate statutory tax rate of $30 \%$. The BTD is calculated by subtracting TI from pre-tax accounting income (AI): $\mathrm{BTD}_{\mathrm{it}}=\mathrm{AI}_{\mathrm{it}}-\mathrm{TI}_{\mathrm{it}}$. The BTD is scaled by lagged total assets. The sample is not restricted to firms with positive BTD as those firms with TI > AI can and do use CFTLs to reduce the amount of corporate taxes paid. Total accruals (TA) were calculated for each firm in each year using a measure of total accruals developed by Healy (1985). TAs is considered to measure the earnings management component of BTD and is computed as follows:

$\mathrm{TA}_{\mathrm{it}}=\mathrm{EBEI}_{\mathrm{it}}-\mathrm{CFO}_{\mathrm{it}}$

where:

i $\quad=$ firms 1-200;

$\mathrm{t} \quad=$ financial years 2006-2010;

TA $\quad=$ total accruals;

EBEI $\quad=$ Pre-tax income; and

CFO $=$ cash flows from operations.

The following OLS regression is performed to account for the component of BTD attributable to earnings management:

$$
\mathrm{BTD}_{\mathrm{it}}=\beta_{1} \mathrm{TAC}_{\mathrm{it}}+\mu_{\mathrm{it}}+\varepsilon_{\mathrm{it}}
$$
where:

BTD $=$ the book-tax difference scaled by lagged total assets;

TA $\quad=\quad$ total accruals scaled by lagged total assets;

$\mu \quad=$ the residual; and

$\varepsilon \quad=\quad$ the error term.

The residual value of BTD is considered by Desai and Dharmapala (2006) to reflect tax avoidance activity (TA): $\mathrm{TA}_{\mathrm{it}}=\mu_{\mathrm{it}}+\varepsilon_{\mathrm{it}}$. 
Table 1

Descriptive Statistics

\begin{tabular}{|c|c|c|c|c|c|}
\hline Variable & Mean & Std. Dev. & Minimum & Median & Maximum \\
\hline ETR1 & 0.160 & 0.189 & 0.000 & 0.095 & 0.706 \\
\hline ETR2 & 0.195 & 0.229 & 0.000 & 0.147 & 0.752 \\
\hline BTAX1 & 0.029 & 0.247 & -0.649 & 0.001 & 0.316 \\
\hline BTAX2 & -0.003 & 0.665 & -3.233 & 0.125 & 1.417 \\
\hline TRU & 0.373 & 0.484 & 0.000 & 0.000 & 1.000 \\
\hline TAXEXP & 0.083 & 0.276 & 0.000 & 0.000 & 1.000 \\
\hline TAXAFF & 0.086 & 0.281 & 0.000 & 0.000 & 1.000 \\
\hline REM & 0.345 & 0.238 & 0.000 & 0.316 & 0.950 \\
\hline SIZE & 20.399 & 1.916 & 13.823 & 20.437 & 25.586 \\
\hline LEV & 0.442 & 0.253 & 0.000 & 0.471 & 2.719 \\
\hline CINT & 0.345 & 0.767 & 0.000 & 0.227 & 0.759 \\
\hline RDINT & 0.007 & 0.037 & 0.000 & 0.000 & 0.537 \\
\hline INVINT & 0.015 & 0.053 & 0.000 & 0.000 & 0.584 \\
\hline CFTL & 0.705 & 0.456 & 0.000 & 1.000 & 1.000 \\
\hline THAV & 0.145 & 0.353 & 0.000 & 0.000 & 1.000 \\
\hline MKTBK & 5.106 & 41.543 & -4.901 & 2.345 & 86.475 \\
\hline ROA & 0.079 & 0.151 & -0.002 & 0.061 & 0.358 \\
\hline BODI & 0.651 & 0.176 & 0.000 & 0.667 & 1.000 \\
\hline AUD & 0.852 & 0.356 & 0.000 & 1.000 & 1.000 \\
\hline CEO & 1.457 & 0.991 & 0.000 & 1.609 & 3.526 \\
\hline
\end{tabular}

Variable definitions: ETR1 = income tax expense scaled by pre-tax accounting income; ETR2 = cash tax paid scaled by pre-tax accounting income; BTAX1 = pre-tax accounting income less taxable income (where taxable income is computed as income tax expense divided by the statutory corporate tax rate of 30\%) using the method developed by Manzon and Plesko (2002) scaled by lagged (preceding year) total assets; BTAX2 = book-tax difference residual calculated using the method developed by Desai and Dharmapala (2006); TRU = a dummy variable of 1 if the firm discloses a significant uncertainty of its tax position and 0 otherwise; TAXEXP = a dummy variable of 1 if at least one member of the board of directors has tax expertise (i.e., prior experience in tax accounting or tax-related audit work) and 0 otherwise; TAXAFF = a dummy variable of 1 if at least one member of the board of directors has a minimum of one affiliation to a tax-related professional body (i.e., The Board of Taxation and/or The Institute of Taxation) and 0 otherwise; REM = the total performance based remuneration paid to key management personnel (the total at-risk cash bonus and total equity-based remuneration paid to the key management personnel) scaled by the total remuneration paid to key management personnel; SIZE $=$ the natural logarithm of total assets; LEV = long-term debt scaled by total assets; CINT = net property, plant and equipment scaled by total assets; RDINT $=$ R\&D expenditure scaled by total assets; INVINT $=$ total inventory scaled by total assets; CFTL $=$ a dummy variable of 1 when a firm has a carry-forward tax loss and 0 otherwise; THAV = a dummy variable of 1 if the firm has at least one subsidiary firm incorporated in an OECD (2006) listed tax haven and 0 otherwise; MKTBK = the market value of equity scaled by the book value of equity; ROA = the pre-tax income scaled by total assets; BODI $=$ the proportion of board members who are independent directors; AUD $=\mathrm{a}$ dummy variable of 1 if the firm employs a Big- 4 external auditor and 0 otherwise; and CEO = the natural logarithm of the CEO's tenure.

$\mathrm{N}=1,000$ for all variables. 
Table 2

Pearson Correlation Results

\begin{tabular}{|c|c|c|c|c|c|c|c|c|c|c|c|c|c|c|c|c|c|c|c|c|c|}
\hline & & $\begin{array}{l}\text { ETR1 } \\
\end{array}$ & ETR2 & BTAX1 & BTAX2 & 1. & 2. & 3. & 4. & 5. & 6. & 7. & 8. & 9. & 10 & 11 & 12. & 13. & 14. & 15. & 16. \\
\hline 1. & $\begin{array}{l}\text { TRU } \\
\end{array}$ & $\begin{array}{l}-0.015 \\
\end{array}$ & $\begin{array}{l}-0.014 \\
-0.017 * *\end{array}$ & $\begin{array}{l}0.024 \\
\end{array}$ & $\begin{array}{l}0.063^{* * *} \\
0.077^{* *}\end{array}$ & 0.008 & & & & & & & & & & & & & & & \\
\hline 2. & TAXEXP & $-0.086 * * * *$ & & 0.034 & $\begin{array}{l}0.077^{* *} \\
0.189 * *\end{array}$ & 0.008 & & & & & & & & & & & & & & & \\
\hline 3. & TAXAFF & $0.087 * * *$ & $\begin{array}{l}0.101^{* * *} \\
-0,8 * *\end{array}$ & -0.005 & $-0.189^{* * * *}$ & 0.036 & 0.014 & - & & & & & & & & & & & & & \\
\hline 4. & $\begin{array}{l}\text { REM } \\
\text { SIZE }\end{array}$ & $\begin{array}{c}-0.029 * * * \\
-0.159 * *\end{array}$ & $\begin{array}{c}-0.068^{* * *} * * \\
-0.302 *\end{array}$ & $\begin{array}{l}0.022 \\
0.024\end{array}$ & $\begin{array}{l}0.029 \\
0.042\end{array}$ & $\begin{array}{l}0.018 \\
0.127 * * *\end{array}$ & 0.041 & $\begin{array}{l}-0.18 \\
-0.010\end{array}$ & $\begin{array}{c}- \\
0348 * * *\end{array}$ & & & & & & & & & & & & \\
\hline $\begin{array}{l}5 . \\
6 .\end{array}$ & $\begin{array}{l}\text { DILE } \\
\text { LEV }\end{array}$ & $\begin{array}{l}-0.159 \\
-0.179 * * *\end{array}$ & $\begin{array}{l}-0.302 \\
-0.243 * * *\end{array}$ & $\begin{array}{l}0.024 \\
0.020\end{array}$ & $\begin{array}{c}0.042 \\
0.257 * * *\end{array}$ & 0.044 & $\begin{array}{l}0.010 \\
0.031\end{array}$ & $\begin{array}{l}-0.010 \\
0.047\end{array}$ & $0.097 \% * * *$ & $0.425 * * *$ & & & & & & & & & & & \\
\hline 7. & $\begin{array}{l}\text { LEV } \\
\text { CINT }\end{array}$ & -0.014 & $-0.067 * *$ & $\begin{array}{l}0.020 \\
0.016\end{array}$ & 0.043 & 0.034 & $\begin{array}{r}-.031 \\
-0.036\end{array}$ & $\begin{array}{c}0.041 \\
0.116^{* * *}\end{array}$ & -0.030 & $0.097 * * *$ & -0007 & & & & & & & & & & \\
\hline 8. & RDINT & $-0.062 * *$ & -0.049 & 0.009 & 0.008 & $0.096 * * *$ & $-0.052^{*}$ & -0.047 & & -0.014 & $-0.132 * * * *$ & -0.051 & & & & & & & & & \\
\hline 9. & INVINT & 0.023 & 0.025 & -0.006 & $-0.123^{* * * *}$ & -0.043 & 0.012 & -0.015 & -0.037 & $0.081 * * *$ & 0.043 & $0.103 * * *$ & -0.044 & & & & & & & & \\
\hline 10. & CFTL & $-0.113^{* * * *}$ & $-0.148^{* * * *}$ & $0.075 * *$ & $0.079 * * *$ & 0.040 & $0.068^{* * *}$ & -0.029 & $0.053^{*}$ & $-0.055^{*}$ & $-0.111^{* * * *}$ & $-0.063 * *$ & $0.101^{* * * *}$ & $-0.157 * * *$ & & & & & & & \\
\hline 11. & THAV & $-0.055^{*}$ & $-0.081^{* * *}$ & 0.026 & 0.006 & $0.188^{* * * *}$ & 0.030 & $0.106 * * *$ & $0.186^{* * * *}$ & $0.367 * * *$ & $0.135 * * *$ & $0.081^{* *}$ & $-0.061^{*}$ & $0.121^{* * *}$ & $0.117^{* * *}$ & - & & & & & \\
\hline 12. & MKTBK & 0.024 & 0.031 & 0.001 & 0.022 & 0.050 & -0.009 & -0.008 & -0.019 & $0.145^{* * * *}$ & 0.008 & 0.046 & 0.025 & 0.001 & 0.022 & -0.018 & & & & & \\
\hline 13. & ROA & 0.007 & 0.028 & $0.316^{* * * *}$ & $0.333^{* * * *}$ & -0.021 & -0.020 & -0.011 & 0.020 & 0.024 & 0.001 & -0.012 & -0.017 & 0.004 & $-0.087^{* * * *}$ & -0.001 & 0.012 & & & & \\
\hline 14. & BODI & $0.119 * * *$ & $0.155^{* * * *}$ & -0.035 & $-0.096 * * *$ & 0.025 & $-0.098 * * *$ & $0.056^{*}$ & $0.157^{* * * *}$ & $0.286 * * *$ & $0.136 * * *$ & -0.014 & $0.100^{* * * *}$ & -0.013 & -0.022 & $-0.157^{* * * *}$ & -0.017 & -0.028 & 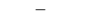 & & \\
\hline 15. & AUD & $0.157^{* * *}$ & $0.187^{* * *}$ & -0.005 & ${ }^{-0.046}$ & $0.071^{* * *}$ & $\begin{array}{l}-0.038 \\
-016\end{array}$ & 0.048 & $0.138^{* * 4 *}$ & $0.323^{* * * 4}$ & $0.171^{* * * *}$ & $0.066^{* * *}$ & $0.080^{* * *}$ & 0.042 & -0.041 & $-0.108^{* * * *}$ & 0.004 & $0.052^{*}$ & $0.301^{* * * *}$ & 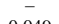 & \\
\hline 16. & CEO & $-0.104^{* * * *}$ & $-0.103^{* * *}$ & 0.025 & 0.014 & $-0.060^{*}$ & -0.016 & -0.025 & -0.002 & -0.049 & $0.058^{*}$ & $-0.061^{*}$ & 0.040 & -0.014 & 0.039 & 0.021 & -0.016 & -0.008 & 0.050 & 0.049 & - \\
\hline
\end{tabular}

Variable definitions: ETR1 = income tax expense scaled by pre-tax accounting income; ETR2 = cash tax paid scaled by pre-tax accounting income; BTAX1 = pre-tax accounting income less taxable income (where taxable income is computed as income tax expense divided by the statutory corporate tax rate of 30\%) using the method developed by Manzon and Plesko (2002) scaled by lagged (preceding year) total assets; BTAX2 = book-tax difference residual calculated using the method developed by Desai and Dharmapala (2006); TRU = a dummy variable of 1 if the firm discloses a significant uncertainty of its tax position and 0 otherwise; TAXEXP $=$ a dummy variable of 1 if at least one member of the board of directors has tax expertise (i.e., prior experience in tax accounting or tax-related audit work) and 0 otherwise; TAXAFF = a dummy variable of 1 if at least one member of the board of directors has a minimum of one affiliation to a tax-related professional body (i.e., The Board of Taxation and/or The Institute of Taxation) and 0 otherwise; REM = the total performance based remuneration paid to key management personnel (the total at-risk cash bonus and total equity-based remuneration paid to the key management personnel) scaled by the total remuneration paid to key management personnel; SIZE = the natural logarithm of total assets; LEV = long-term debt scaled by total assets; CINT = net property, plant and equipment scaled by total assets; RDINT = R\&D expenditure scaled by total assets; INVINT = total inventory scaled by total assets; CFTL $=$ a dummy variable of 1 when a firm has a carry-forward tax loss and 0 otherwise; THAV = a dummy variable of 1 if the firm has at least one subsidiary firm incorporated in an OECD (2006) listed tax haven and 0 otherwise; MKTBK = the market value of equity scaled by the book value of equity; ROA = the pre-tax income scaled by total assets; BODI = the proportion of board members who are independent directors; AUD = a dummy variable of 1 if the firm employs a Big-4 external auditor and 0 otherwise; and CEO = the natural logarithm of the CEO's tenure.

$\mathrm{N}=1,000$ for all variables.

${ }^{*}, * *$, and *** indicate significance at the $.10, .05$, and .01 levels, respectively. The $p$-values are based on two-tailed tests of significance. 
Table 3

Regression Results

\begin{tabular}{|c|c|c|c|c|c|c|}
\hline Variable & Predicted Sign & ETR1 $^{\mathrm{a}}$ & ETR2 $^{a}$ & Predicted Sign & $\mathrm{BTAX}^{\mathrm{a}}$ & $\mathrm{BTAX}^{\mathrm{a}}$ \\
\hline Intercept & ? & $\begin{array}{c}-0.603 \\
(-4.98)^{* * *}\end{array}$ & $\begin{array}{l}-0.223 \\
(-1.19)\end{array}$ & ? & $\begin{array}{c}-0.034 \\
(-1.79)^{*}\end{array}$ & $\begin{array}{c}-0.944 \\
(-3.14)^{* * *}\end{array}$ \\
\hline TRU & - & $\begin{array}{c}-0.004 \\
(-.23)\end{array}$ & $\begin{array}{c}-0.018 \\
(-1.76)^{*}\end{array}$ & + & $\begin{array}{c}0.040 \\
(1.92)^{*}\end{array}$ & $\begin{array}{c}0.128 \\
(3.90)^{* * *}\end{array}$ \\
\hline TAXEXP & ? & $\begin{array}{c}-0.035 \\
(-1.96)^{* *}\end{array}$ & $\begin{array}{l}-0.018 \\
(-1.06)\end{array}$ & $?$ & $\begin{array}{c}0.033 \\
(1.88)^{*}\end{array}$ & $\begin{array}{c}0.167 \\
(3.39)^{* * *}\end{array}$ \\
\hline TAXAFF & + & $\begin{array}{c}0.066 \\
(2.24)^{* *}\end{array}$ & $\begin{array}{c}0.072 \\
(3.15)^{* * *}\end{array}$ & - & $\begin{array}{l}-0.006 \\
(-0.26)\end{array}$ & $\begin{array}{c}-0.457 \\
(-3.34)^{* * *}\end{array}$ \\
\hline REM & - & $\begin{array}{c}-0.023 \\
(-1.74)^{*}\end{array}$ & $\begin{array}{c}-0.028 \\
(-2.03)^{* *}\end{array}$ & + & $\begin{array}{l}0.057 \\
(1.56)\end{array}$ & $\begin{array}{c}0.110 \\
(1.96)^{* *}\end{array}$ \\
\hline SIZE & - & $\begin{array}{c}-0.017 \\
(-2.89)^{* * *}\end{array}$ & $\begin{array}{c}-0.030 \\
(-3.61)^{* * *}\end{array}$ & + & $\begin{array}{c}0.196 \\
(2.70)^{* * *}\end{array}$ & $\begin{array}{c}0.013 \\
(.84)\end{array}$ \\
\hline LEV & - & $\begin{array}{c}-0.056 \\
(-1.82)^{*}\end{array}$ & $\begin{array}{l}-0.025 \\
(-1.12)\end{array}$ & + & $\begin{array}{c}0.115 \\
(2.65)^{* * *}\end{array}$ & $\begin{array}{c}0.594 \\
(2.98)^{* * *}\end{array}$ \\
\hline CINT & - & $\begin{array}{l}0.010 \\
(1.08)\end{array}$ & $\begin{array}{l}-.006 \\
(-1.47)\end{array}$ & + & $\begin{array}{l}0.025 \\
(1.49)\end{array}$ & $\begin{array}{c}.002 \\
(0.09)\end{array}$ \\
\hline RDINT & - & $\begin{array}{l}-0.188 \\
(-1.02)\end{array}$ & $\begin{array}{l}0.070 \\
(0.32)\end{array}$ & + & $\begin{array}{l}0.019 \\
(0.88)\end{array}$ & $\begin{array}{c}0.576 \\
(1.72)^{*}\end{array}$ \\
\hline INVINT & + & $\begin{array}{l}0.002 \\
(0.01)\end{array}$ & $\begin{array}{c}0.176 \\
(1.80)^{* *}\end{array}$ & - & $\begin{array}{l}-0.011 \\
(-0.32)\end{array}$ & $\begin{array}{c}-0.007 \\
(-2.84)^{* * *}\end{array}$ \\
\hline CFTL & - & $\begin{array}{c}-0.048 \\
(-2.77)^{* * *}\end{array}$ & $\begin{array}{c}-0.040 \\
(-2.97)^{* * *}\end{array}$ & + & $\begin{array}{l}.056 \\
(1.87)^{*}\end{array}$ & $\begin{array}{c}.044 \\
(2.02)^{* *}\end{array}$ \\
\hline THAV & - & $\begin{array}{l}-0.023 \\
(-0.95)\end{array}$ & $\begin{array}{l}-0.021 \\
(-1.02)\end{array}$ & + & $\begin{array}{l}0.068 \\
(1.39)\end{array}$ & $\begin{array}{l}0.023 \\
(0.42)\end{array}$ \\
\hline MKTBK & ? & $\begin{array}{l}-0.001 \\
(-1.22)\end{array}$ & $\begin{array}{l}-0.001 \\
(-0.17)\end{array}$ & ? & $\begin{array}{l}0.017 \\
(1.81)\end{array}$ & $\begin{array}{c}.001 \\
(2.80)^{* * *}\end{array}$ \\
\hline ROA & ? & $\begin{array}{l}-0.002 \\
(-.76)\end{array}$ & $\begin{array}{l}-0.001 \\
(-.22)\end{array}$ & ? & $\begin{array}{c}0.031 \\
(3.51)^{* * *}\end{array}$ & $\begin{array}{c}.031 \\
(3.60)^{* * *}\end{array}$ \\
\hline BODI & + & $\begin{array}{l}0.001 \\
(0.01)\end{array}$ & $\begin{array}{l}0.030 \\
(0.89)\end{array}$ & - & $\begin{array}{l}-0.047 \\
(-1.35)\end{array}$ & $\begin{array}{l}-0.024 \\
(-0.23)\end{array}$ \\
\hline AUD & ? & $\begin{array}{c}0.059 \\
(2.81)^{* * *}\end{array}$ & $\begin{array}{c}0.040 \\
(2.55)^{* *}\end{array}$ & ? & $\begin{array}{c}-0.059 \\
(-2.89)^{* * *}\end{array}$ & $\begin{array}{l}-0.044 \\
(-1.02)\end{array}$ \\
\hline CEO & ? & $\begin{array}{c}-0.025 \\
(-3.35)^{* * *}\end{array}$ & $\begin{array}{c}-0.017 \\
(-3.00)^{* * *}\end{array}$ & ? & $\begin{array}{c}0.033 \\
(1.82)^{*}\end{array}$ & $\begin{array}{l}0.020 \\
(1.10)\end{array}$ \\
\hline INDSEC & ? & Yes & Yes & ? & Yes & Yes \\
\hline YEAR & ? & Yes & Yes & ? & Yes & Yes \\
\hline Adj. R² (\%) & & $13.44 \%$ & $23.64 \%$ & & $26.07 \%$ & $52.55 \%$ \\
\hline $\mathrm{N}$ & & 1,000 & 1,000 & & 1,000 & 1,000 \\
\hline
\end{tabular}

Variable definitions: ETR1 = income tax expense scaled by pre-tax accounting income; ETR2 = cash tax paid scaled by pre-tax accounting income; BTAX1 = pre-tax accounting income less taxable income (where taxable income is computed as income tax expense divided by the statutory corporate tax rate of 30\%) using the method developed by Manzon and Plesko (2002) scaled by lagged (preceding year) total assets; BTAX2 = book-tax difference residual calculated using the method developed by Desai and Dharmapala (2006); TRU = a dummy variable of 1 if the firm discloses a significant uncertainty of its tax position and 0 otherwise; TAXEXP = a dummy variable of 1 if at least one member of the board of directors has tax expertise (i.e., prior experience in tax accounting or tax-related audit work) and 0 otherwise; TAXAFF = a dummy variable of 1 if at least one member of the board of directors has a minimum of one affiliation to a tax-related professional body (i.e., The Board of Taxation and/or The Institute of Taxation) and 0 otherwise; REM = the total performance based remuneration paid to key management personnel (the total at-risk cash bonus and total equity-based remuneration paid to the key management personnel) scaled by the total remuneration paid to key management personnel; SIZE = the natural logarithm of total assets; LEV = long-term debt scaled by total assets; CINT = net property, plant and equipment scaled by total assets; RDINT = R\&D expenditure scaled by total assets; INVINT = total inventory scaled by total assets; CFTL = a dummy variable of 1 when a firm has a carry-forward tax loss and 0 otherwise; THAV = a dummy variable of 1 if the firm has at least one subsidiary firm incorporated in an OECD (2006) listed tax haven and 0 otherwise; MKTBK = the market value of equity scaled by the book value of equity; ROA = the pre-tax income scaled by total assets; BODI = the proportion of board members who are independent directors; AUD = a dummy variable of 1 if the firm employs a Big-4 external auditor and 0 otherwise; and CEO = the natural logarithm of the CEO's tenure; INDSEC $=$ an industry sector dummy variable of 1 if the firm is represented in the specific GICS category and 0 otherwise; and YEAR = a year dummy variable of 1 if the year falls 
within the specific year category and 0 otherwise.

$*$, **, and $* * *$ indicate significance at the $.10, .05$, and .01 levels, respectively. The $p$-values are based on two-tailed tests of significance.

${ }^{\mathrm{a} C o e f f i c i e n t}$ estimates with the $t$-statistics in parentheses. Standard errors are corrected using the White (1980) procedure. 
Table 4

Regression Results - Using Matched Samples

\begin{tabular}{|c|c|c|c|c|c|c|c|c|c|c|c|c|}
\hline \multicolumn{13}{|c|}{ 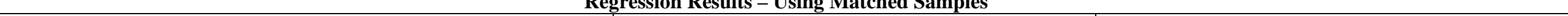 } \\
\hline & \multicolumn{4}{|c|}{ Matched Sample Based on TAXEXP } & \multicolumn{4}{|c|}{ Matched Sample Based on TAXAFF } & \multicolumn{4}{|c|}{ Matched Sample Based on REM } \\
\hline Variable & ETR1 $^{\mathrm{a}}$ & ETR2 $^{\mathrm{a}}$ & $\mathrm{BTAX}^{\mathrm{a}}$ & BTAX2 $^{a}$ & ETR1 $^{\mathrm{a}}$ & ETR2 $^{\mathrm{a}}$ & $\mathrm{BTAX}^{\mathrm{a}}$ & BTAX2 $^{a}$ & ETR1 $^{\mathrm{a}}$ & ETR2 $^{\mathrm{a}}$ & $\mathrm{BTAX}^{\mathrm{a}}$ & BTAX2 $^{\text {a }}$ \\
\hline \multirow{2}{*}{ Intercept } & -0.383 & -0.293 & -0.065 & -0.654 & -0.441 & -0.346 & -0.095 & -0.968 & -0.486 & -0.553 & -0.037 & -0.967 \\
\hline & $(-2.04)^{* *}$ & $(-1.06)$ & $(-1.28)$ & $(-2.31)^{* *}$ & $(-1.56)$ & $(-1.28)$ & $(-1.22)$ & $(-3.02)^{* * *}$ & $(-4.48)^{* * *}$ & $(-3.98)^{* * *}$ & $(-.71)$ & $(-2.59)^{* * *}$ \\
\hline \multirow{2}{*}{ TRU } & -0.007 & -0.049 & 0.048 & 0.346 & -0.051 & -0.025 & 0.056 & 0.321 & -0.027 & -0.038 & 0.041 & 0.112 \\
\hline & $(-.59)$ & $(-2.26)^{* *}$ & $(1.98)^{* *}$ & $(2.66)^{* * *}$ & $(-1.07)$ & $(-1.96)^{* *}$ & $(2.30)^{* *}$ & $(3.24)^{* * *}$ & $(-1.13)$ & $(-2.00)^{* *}$ & $(1.96)^{* *}$ & $(2.11)^{* *}$ \\
\hline \multirow{2}{*}{ TAXEXP } & -0.034 & -0.049 & 0.050 & 0.256 & -0.031 & -0.042 & 0.057 & 0.264 & -0.032 & -0.020 & 0.001 & 0.208 \\
\hline & $(-1.79)^{*}$ & $(-1.94)^{*}$ & $(.44)$ & $(3.74)^{* * *}$ & $(-1.80)^{*}$ & $(-2.30) * *$ & $(.93)$ & $(2.45)^{* *}$ & $(-1.85)^{*}$ & $(-.89)$ & $(.35)$ & $(2.73)^{* * *}$ \\
\hline \multirow{2}{*}{ TAXAFF } & 0.073 & 0.051 & -0.093 & -0.547 & 0.077 & 0.063 & -0.084 & -0.441 & 0.067 & 0.054 & -0.041 & -0.497 \\
\hline & $(2.29)^{* *}$ & $(2.19)^{* *}$ & $(-0.76)$ & $(-3.04)^{* * *}$ & $(2.26)^{* *}$ & $(2.18)^{* *}$ & $(-1.04)$ & $(-3.68) * * *$ & $(1.96)^{* *}$ & $(1.96)^{* *}$ & $(-1.30)$ & $(-3.36)^{* * *}$ \\
\hline \multirow{2}{*}{ REM } & -0.035 & -0.092 & 0.050 & 0.103 & -0.089 & -0.163 & 0.097 & 0.090 & -0.027 & -0.032 & 0.032 & 0.140 \\
\hline & $(-1.72)^{*}$ & $(-1.68)^{*}$ & $(1.51)$ & $(1.98)^{* *}$ & $(-2.39)^{* *}$ & $(-2.24) * *$ & $(1.94)^{*}$ & $(1.97)^{* *}$ & $(-0.71)$ & $(-2.05)^{* *}$ & $(.49)$ & $(2.06)^{* *}$ \\
\hline \multirow{2}{*}{ SIZE } & -0.024 & -0.18 & 0.165 & 0.113 & -0.025 & -0.28 & 0.170 & 0.131 & -0.026 & -0.039 & 0.145 & 0.009 \\
\hline & $(-1.67)^{* *}$ & $(-1.71)^{*}$ & $(2.22)^{* *}$ & $(2.76)^{* * *}$ & $(-1.60)$ & $(-1.99)^{* *}$ & $(2.25)^{* *}$ & $(2.54)^{* *}$ & $(-3.10)^{* * *}$ & $(-3.32)^{* * *}$ & $(2.33)^{* *}$ & $(.53)$ \\
\hline \multirow{2}{*}{ LEV } & -0.134 & -0.057 & 0.003 & 0.556 & -0.007 & -0.076 & 0.049 & 0.514 & -0.043 & -0.040 & 0.053 & 0.634 \\
\hline & $(-1.57)$ & $(-.70)$ & $(0.04)$ & $(2.53)^{* * *}$ & $(-0.08)$ & $(-.87)$ & $(0.73)$ & $(2.43)^{* *}$ & $(-1.05)$ & $(-1.06)$ & (1.15) & $(3.05)^{* * *}$ \\
\hline \multirow{2}{*}{ CINT } & 0.045 & -.047 & 0.109 & .139 & 0.057 & -.016 & 0.061 & .116 & 0.026 & -.021 & 0.017 & .009 \\
\hline & (.37) & $(-.54)$ & $(2.18)^{* *}$ & $(0.69)$ & (1.09) & $(-.88)$ & $(1.84)^{*}$ & $(0.60)$ & (.99) & $(-2.10) * *$ & $(.52)$ & $(0.20)$ \\
\hline \multirow{2}{*}{ RDINT } & -0.114 & 0.078 & 0.021 & 0.384 & -0.117 & 0.050 & 0.031 & 0.352 & -0.164 & 0.010 & 0.020 & 0.278 \\
\hline & $(-.98)$ & $(0.48)$ & $(0.39)$ & $(1.02)$ & $(-1.07)$ & $(0.78)$ & (1.11) & $(.40)$ & $(-.72)$ & $(0.05)$ & $(0.71)$ & $(.40)$ \\
\hline \multirow{2}{*}{ INVINT } & 0.363 & 0.068 & -0.039 & -0.029 & 0.326 & 0.031 & -0.086 & -0.108 & 0.092 & 0.289 & -0.020 & -0.320 \\
\hline & (1.18) & $(.20)$ & $(-0.45)$ & $(-1.37)$ & $(.56)$ & (.78) & $(-1.07)$ & $(-1.49)^{*}$ & $(0.28)$ & $(2.18)^{* *}$ & $(-0.31)$ & $(-3.01)^{* * *}$ \\
\hline \multirow{2}{*}{ CFTL } & -0.106 & -0.033 & .003 & .111 & -0.075 & -0.083 & .099 & .312 & -0.041 & -0.050 & .042 & .105 \\
\hline & $(-2.05)^{* *}$ & $(-1.97)^{* *}$ & $(0.06)$ & $(1.90)^{*}$ & $(-1.88)^{*}$ & $(-2.29) * *$ & (1.41) & $(2.89) * * *$ & $(-2.07)^{* *}$ & $(-2.07) * *$ & $(1.75)^{*}$ & $(1.98)^{* *}$ \\
\hline \multirow{2}{*}{ THAV } & -0.040 & -0.020 & 0.038 & 0.021 & -0.056 & -0.069 & 0.071 & 0.037 & -0.025 & -0.017 & 0.002 & 0.018 \\
\hline & $(-0.64)$ & $(-.45)$ & $(.30)$ & $(0.15)$ & $(-1.10)$ & $(-1.02)$ & $(.92)$ & $(0.79)$ & $(-0.96)$ & $(-.76)$ & $(.03)$ & $(0.28)$ \\
\hline \multirow{2}{*}{ MKTBK } & -0.001 & -0.001 & 0.045 & .006 & -0.003 & -0.002 & 0.087 & .013 & -0.003 & -0.004 & 0.010 & .009 \\
\hline & $(-.32)$ & $(-0.10)$ & $(1.02)$ & (1.04) & $(-.61)$ & $(-0.48)$ & $(1.32)$ & (1.34) & $(-1.09)$ & $(-0.21)$ & $(.27)$ & $(.42)$ \\
\hline \multirow{2}{*}{ ROA } & -0.016 & -0.018 & 0.060 & .178 & -0.049 & -0.019 & 0.137 & .156 & -0.002 & -0.001 & 0.018 & .011 \\
\hline & $(-1.58)$ & $(-.27)$ & $(1.82)^{*}$ & $(.77)$ & $(-.40)$ & $(-1.06)$ & $(1.07)$ & $(.86)$ & $(-1.03)$ & $(-.27)$ & $(.42)$ & $(.82)$ \\
\hline \multirow{2}{*}{ BODI } & 0.049 & 0.066 & -0.082 & -0.441 & 0.036 & 0.016 & -0.046 & -0.473 & 0.095 & 0.034 & -0.071 & -0.071 \\
\hline & $(0.50)$ & $(1.04)$ & $(-.93)$ & $(-1.98)^{* *}$ & $(0.28)$ & $(.15)$ & $(-.37)$ & $(-1.31)$ & $(1.47)$ & $(0.70)$ & $(.48)$ & $(-0.48)$ \\
\hline \multirow{2}{*}{ AUD } & 0.031 & 0.102 & -0.052 & -0.097 & 0.029 & 0.064 & -0.035 & -0.167 & 0.054 & 0.052 & -0.058 & -0.058 \\
\hline & $(1.68)^{*}$ & $(2.48)^{* *}$ & $(-2.00)^{* *}$ & $(-.65)$ & $(1.78)^{*}$ & $(2.00)^{* *}$ & $(-2.34)^{* *}$ & $(-.69)$ & $(2.27)^{* *}$ & $(2.37)^{* *}$ & $(-2.78)^{* * *}$ & $(-.78)$ \\
\hline \multirow{2}{*}{ CEO } & -0.024 & -0.043 & 0.062 & 0.035 & -0.048 & -0.023 & 0.002 & 0.052 & -0.025 & -0.014 & 0.046 & 0.036 \\
\hline & $(-2.01)^{* *}$ & $(-2.65) * * *$ & $(1.84)^{*}$ & $(.63)$ & $(-3.15) * * *$ & $(-1.69)^{*}$ & $(.05)$ & $(1.34)$ & $(-2.47) * *$ & $(-1.88)^{*}$ & $(2.12)^{* *}$ & $(1.10)$ \\
\hline INDSEC & Yes & Yes & Yes & Yes & Yes & Yes & Yes & Yes & Yes & Yes & Yes & Yes \\
\hline
\end{tabular}




\begin{tabular}{|c|c|c|c|c|c|c|c|c|c|c|c|c|}
\hline YEAR & Yes & Yes & Yes & Yes & Yes & Yes & Yes & Yes & Yes & Yes & Yes & Yes \\
\hline Adj. R (\%) & $19.95 \%$ & $25.55 \%$ & $19.62 \%$ & $42.44 \%$ & $12.56 \%$ & $16.82 \%$ & $18.10 \%$ & $41.47 \%$ & $19.20 \%$ & $22.85 \%$ & $19.60 \%$ & $32.94 \%$ \\
\hline $\mathrm{N}$ & 168 & 168 & 168 & 168 & 172 & 172 & 172 & 172 & 512 & 512 & 512 & 512 \\
\hline
\end{tabular}

Propensity matching analysis was conducted in two steps. First, we implement separate logit regression models for TAXEXP and TAXAFF, and OLS regression models for REM for each year. The explanatory variables used in each model are TRU and the control variables. TAXEXP, TAXAFF and REM are also variably included as independent variables contingent on the dependent variable used. The predicted estimates from each model are used as the propensity scores for each firm-year observation. Second, we form one-to-one matched pairs for each of TAXEXP, TAXAFF and REM based on the propensity scores. We were able to effectively match a total 168, 172 and 512 firm-year observations for each of TAXEXP, TAXAFF and REM, respectively.

Variable definitions: ETR1 = income tax expense scaled by pre-tax accounting income; ETR2 = cash tax paid scaled by pre-tax accounting income; BTAX1 = pre-tax accounting income less taxable income (where taxable income is computed as income tax expense divided by the statutory corporate tax rate of 30\%) using the method developed by Manzon and Plesko (2002) scaled by lagged (preceding year) total assets; BTAX2 = book-tax difference residual calculated using the method developed by Desai and Dharmapala (2006); TRU = a dummy variable of 1 if the firm discloses a significant uncertainty of its tax position and 0 otherwise; TAXEXP = a dummy variable of 1 if at least one member of the board of directors has tax expertise (i.e., prior experience in tax accounting or tax-related audit work) and 0 otherwise; TAXAFF = a dummy variable of 1 if at least one member of the board of directors has a minimum of one affiliation to a tax-related professional body (i.e., The Board of Taxation and/or The Institute of Taxation) and 0 otherwise; REM = the total performance based remuneration paid to key management personnel (the total at-risk cash bonus and total equity-based remuneration paid to the key management personnel) scaled by the total remuneration paid to key management personnel; SIZE = the natural logarithm of total assets; LEV = long-term debt scaled by total assets; CINT = net property, plant and equipment scaled by total assets; RDINT = R\&D expenditure scaled by total assets; INVINT = total inventory scaled by total assets; CFTL = a dummy variable of 1 when a firm has a carry-forward tax loss and 0 otherwise; THAV = a dummy variable of 1 if the firm has at least one subsidiary firm incorporated in an OECD (2006) listed tax haven and 0 otherwise; MKTBK = the market value of equity scaled by the book value of equity; ROA = the pre-tax income scaled by total assets; BODI = the proportion of board members who are independent directors; AUD = a dummy variable of 1 if the firm employs a Big-4 external auditor and 0 otherwise; and CEO = the natural logarithm of the CEO's tenure; INDSEC = an industry sector dummy variable of 1 if the firm is represented in the specific GICS category and 0 otherwise; and YEAR = a year dummy variable of 1 if the year falls within the specific year category and 0 otherwise. $*, * *$, and *** indicate significance at the $.10, .05$, and .01 levels, respectively. The $p$-values are based on two-tailed tests of significance.

${ }^{a}$ Coefficient estimates with the $t$-statistics in parentheses. Standard errors are corrected using the White (1980) procedure. 